DIW BERLIN

Discussion

Papers

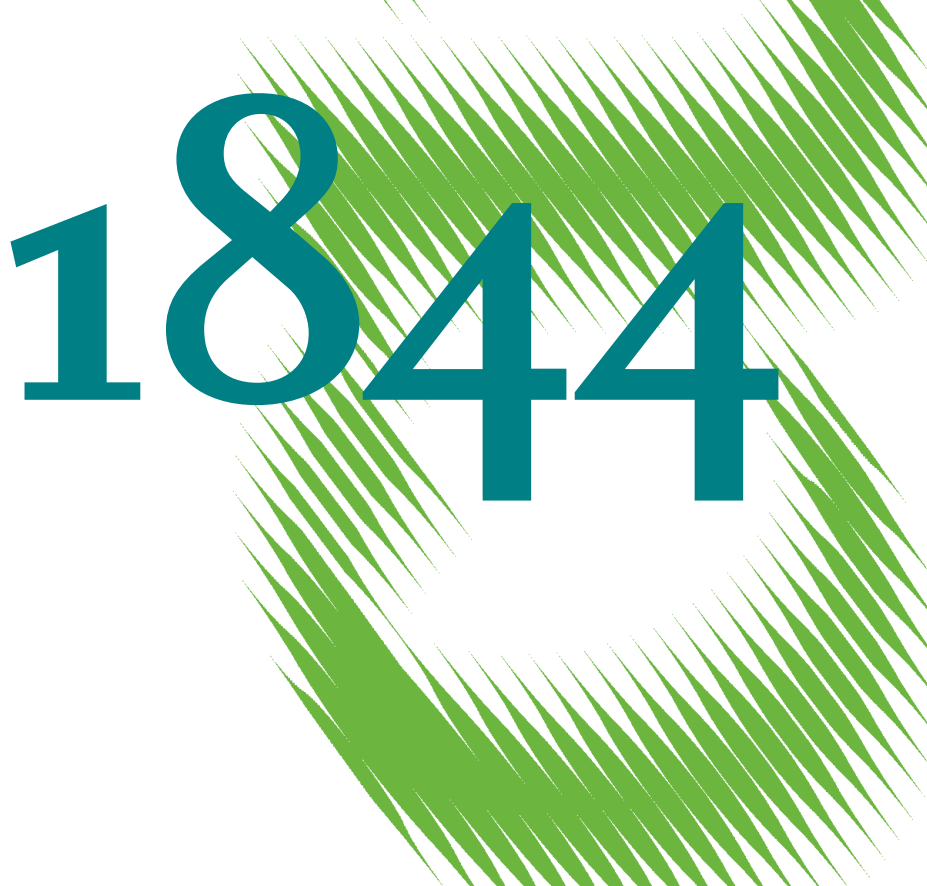

Legal History, Institutions and Banking System Development in Africa 
Opinions expressed in this paper are those of the author(s) and do not necessarily reflect views of the institute.

IMPRESSUM

(C) DIW Berlin, 2020

DIW Berlin

German Institute for Economic Research

Mohrenstr. 58

10117 Berlin

Tel. +49 (30) $89789-0$

Fax +49 (30) $89789-200$

http://www.diw.de

ISSN electronic edition 1619-4535

Papers can be downloaded free of charge from the DIW Berlin website:

http://www.diw.de/discussionpapers

Discussion Papers of DIW Berlin are indexed in RePEc and SSRN:

http://ideas.repec.org/s/diw/diwwpp.html

http://www.ssrn.com/link/DIW-Berlin-German-Inst-Econ-Res.html 


\title{
Legal History, Institutions and Banking System Development in Africa*
}

\author{
Samuel Mutarindwa ${ }^{\dagger} \quad$ Dorothea Schäfer ${ }^{\ddagger} \quad$ Andreas Stephan $^{\S}$
}

January, 2020

\begin{abstract}
This paper links banking systems development to the colonial and legal history of African countries. Specifically, we investigate the impact of differing legal traditions on the development of existing investor and creditor protection, and on African banking systems. Based on a sample of 40 African countries from 2000 to 2016, our empirical findings show a significant dependence of current financial institutions on the legal origin and the colonization type. Findings also reveal that current legal financial institutions are not the major determinants of banking system development, whereas institutional and regulatory quality significantly matter for banking system development in both common and civil law countries. Strong creditor rights reduce the cost of banking in African countries.
\end{abstract}

Key Words: Legal origin, colonial history, financial institutions, banking system, HausmanTaylor estimation

JEL codes: G21,G38,G39,K15,K40

*This paper is a revised version of Chapter 4 of Samuel Mutarindwa's $\mathrm{PhD}$ dissertation (Mutarindwa, 2019). We are particularly grateful to Kit Baum and Thorsten Beck for their helpful comments and suggestions on a previous draft of this paper. We thank Leonidas Barbopoulos and seminar participants at the Nordic Corporate Governance Network conference in Oslo at the BI Norwegian Business School, 1-2 November 2019. The usual disclaimer applies.

†Samuel.Mutarindwa@ju.se, Jönköping University, Sweden; University of Rwanda

¥dschaefer@diw.de, DIW Berlin, Germany; Jönköping University, Sweden; and CERBE, Italy

§andreas.stephan@ju.se, Jönköping University, Sweden and CESIS Stockholm 



\section{Introduction}

African countries' banking systems differ remarkably from those of developing countries outside the continent. African banking systems have lower levels of development as shown by lower financial depths and access. Loans to the private sector as a percentage of GDP ratio is on average only $21 \%$ in African countries, half of the ratio in other developing countries. Bank assets to GDP is also only 57\%, which is half of the amount in developing countries outside Africa (Mlachila et al., 2016). Even among African countries, there are remarkable heterogeneities in terms of private credit. For instance, private credit to GDP is $141 \%$ in South Africa, $87 \%$ in Mauritius and $61 \%$ in Cape Verde, but only 5\% in Chad (Beck \& Cull, 2014).

The central focus of this study is to examine what drives underdevelopment and heterogeneity of the African banking systems. According to the literature, weak institutional infrastructures are prevalent in many African countries. Creditor rights are often poor and contract enforcement is inefficient and involves a lengthy procedure (Beck, Maimbo, Faye, \& Triki, 2011). In many countries financial repression is high (Andrianaivo \& Yartey, 2010).

The law and finance strand of literature claims that the weak legal systems operating in modern African nations are based on and shaped through the history of European colonization (Beck, Levine, \& Demirgüç-Kunt, 2002; La Porta, Lopez-de Silanes, \& Shleifer, 2008; La Porta, Lopez-de Silanes, Shleifer, \& Vishny, 1998). This paper's aim is to disentangle the channels through which the legal family of origin influences the development of legal institutions and, subsequently, of banking systems. In addition, we explore whether the specific type of colonization matters for institution building and banking system development. The study uses country-level data from 40 African countries for the period 2000-2016. We instrument the country-level legal financial institutions Creditor rights, Investor protection and Contract enforcement, and apply the Hausman-Taylor estimator to account for potential endogeneity (Hausman \& Taylor, 1981).

Our empirical analysis reveals several important results. First, consistent with the law and finance proposition (e.g., Beck et al., 2002; La Porta, Lopez-de Silanes, PopEleches, \& Shleifer, 2004), our paper suggests that legal traditions matter. Both British and non-British common law countries are associated with stronger legal financial institutions (creditor rights, investor protection, enforcing contracts) than the countries with a French or other civil law tradition. This finding supports the view that common law jurisdictions implement law that strengthens creditor and investor rights. Interestingly, countries that were colonized by settlers, do have stronger legal financial institutions and also better developed banking systems. This result has not been reported in the literature so far. 
Surprisingly, however, the econometric results do not provide strong support for the second expected channel from stronger legal financial institutions to more highly developed banking systems. Albeit we find evidence that stronger creditor rights reduce the costs of banking, the results taken together imply that current legal financial institutions are not a major determinant of banking system development in African countries. Instead, we find robust evidence that banking system development is related to the institutional and regulatory quality in the respective country.

This paper makes the following contributions. First, it provides largely missed detailed empirical evidence for Africa on the mechanisms through which laws rooted in legal traditions explain the development of legal financial institutions. In particular, the existing law and finance literature remains silent on the specific impact of colonial rule and it ignores differences within the two groups of common law and civil law countries (Beck, Demirgüç-Kunt, \& Levine, 2003; Beck, Demirguc-Kunt, et al., 2005; Caprio, Laeven, \& Levine, 2007; Djankov, Glaeser, La Porta, Lopez-de Silanes, \& Shleifer, 2003). In contrast, the impact of the colonial regime is an important ingredient of this study. In addition, we divide civil law countries into French civil law and other civil law countries colonized by Belgium, Portugal, Italy and Spain, and Germany. Similarly, we distinguish between British common law and other common law states.

Finally, this study contributes to the research on bank-based financial systems in developing economies. Specifically. we borrow from the approaches used in Levine (1998), Levine, Loayza, and Beck (2000), Emenalo, Gagliardi, and Hodgson (2018) and Aluko and Ajayi (2018) to examine the extent to which legal institutions predict the development of African countries' banking systems (depth, breadth and intermediation).

The paper is organized as follows. Section 2 reviews the theoretical and empirical literature linking legal traditions, law development, institutions and banking development. Section 3 presents our methodology. Section 4 discusses the estimation and empirical strategy used, and presents findings. Section 5 provides the conclusions, limitations and possible avenues for future research.

\section{Review of literature and research propositions}

\subsection{Legal traditions, legal systems and institutional development}

According to law and finance theory, legal systems have their origins in either the common law or the civil law legal tradition. Most nations that exist today have either adopted independently, or acquired through conquest or colonization, one or the other of these two legal tradition (La Porta, Lopez-de Silanes, Shleifer, \& Vishny, 1997; La Porta et al., 
1998). These legal traditions endure and persist over time, producing ancillary institutions that influence economic outcomes (La Porta et al., 2008). Common law originates from the British legal tradition that provides higher discretion to the courts to develop laws from already decided cases. Through this use of case law or jurisprudence, judges in common law countries establish legal precedents that are the foundations for the development of the legal system. In contrast, the civil law tradition has its historical roots in the codified laws of the Roman Empire. This canon of Roman laws is the basis for much of the legal development of the civil law countries of Europe, and places emphasis on the use of legislated codes or statutes whereby courts or judges are law enforcers but not law developers. The role of the courts is limited to interpretation and application of statutes and not to the continuing development of laws.

The law and finance literature highlights the channels or mechanisms through which legal traditions affect legal and institutional development. Beck and Levine (2005) suggest that legal origins influence the development of financial systems through political and adaptability channels that are shaped by the specific legal and institutional environment. According to the authors, the political channel reflects the extent to which a country's judiciary/courts make decisions without interference from political authorities. This independence gives the courts the power and freedom to enforce laws that protect small investors or property. Framing new rules by using previous legal cases also causes a higher degree of adaptability in the legal framework.

In contrast, in civil law countries state and legislative authorities have more power to interfere in judicial processes. In particular, the authorities have the right to appoint and tenure judges. One of the consequences of the differences between common law and civil law systems is that civil law judges are restricted from modifying laws through procedural formalism, while common law judges have more flexibility to apply existing precedent cases to a current case.

Based on an international database capturing judicial independence and law development in 71 countries. Porta, Lopez-de Silane, Pop-Eleches, and Shleifer (2002) propose that a common law tradition is associated with stronger judicial independence vìs-à-vìs a civil law tradition, and the degree of independence predicts higher economic and political freedom. Beck and Levine (2005) use the database of Porta et al. (2002) to test whether the described political and adaptability channels through which legal traditions influence the development of financial systems facilitate firms' access to finance. Using case law as a proxy for the adaptability of legal systems, and, judicial independence as a proxy for political independence, they find that the adaptability mechanism affects firms' access to finance more than the political channel. Djankov et al. (2003) use law data in a crosscountry international study of 109 countries to measure the procedures that are employed 
by courts and litigants in the enforcement of property rentals. The collection of bounced checks is used as a proxy for procedural formalism. Their findings suggest that procedural formalism is higher in civil law than in common law countries. They argue that judicial formalism leads to inconsistency, less honesty and corruption in dispute resolutions, particularly in developing countries. In consideration of these studies, we propose that:

Proposition 1: The development of legal institutions protecting both investors and creditors differ in African countries and depend on their legal traditions.

\subsection{Legal financial institutions and banking systems development}

La Porta et al. (1997) use corporate laws to construct the Anti-Director Rights Index (ADRI) as a measure of investor protection institutions. The index specifically measures the extent to which small or minority shareholders are protected from expropriation by corporate insiders. They empirically test this measure in 49 countries and find that common law countries protect investors better than their civil law counterparts. They also use the ADRI to examine the extent to which it explains financial development proxied by the market capitalization of listed firms divided by GDP in both common and civil countries. They find that in common laws countries the equity markets indicator responds more strongly and positively to the index than in civil law countries.

La Porta, Lopez-de Silanes, and Shleifer (2006) combine the ADRI index with laws requiring firms to improve their reporting standards and test whether the constructed scores affect the market capitalization of stock markets. They find a strong link and show the superiority of the common law legal tradition in amplifying this causality link. They infer from this evidence that the combination of ADRI index and scores representing the quality of reporting standards explain the financial development better than the ADRI index alone.

Djankov, La Porta, Lopez-de Silanes, and Shleifer (2008) improve the ADRI and develop a new index of shareholder protection called the Anti Self Dealing Index (ASDI) to measure the extent to which differences in shareholder rights explain stock market development. The cross-country study reveals significant links between the ASDI and the stock market indicator. The positive relationship is found to be stronger in common than in civil law countries.

Creditor protection is the complement to shareholder protection. La Porta et al. (1997) constructed a measure to capture the extent to which creditors are protected in solvency and bankruptcy procedures. They find that higher levels of creditor protection affect financial development more in common law than in civil law countries. Levine et al. (2000) 
assess the effects of creditor rights, contract enforcement and accounting standards on financial intermediation. They find that financial intermediaries only flourish in common law countries in which competent authorities are able to ensure accurate and effective financial reporting and to enforce contracts, and in which the legal system successfully protects creditors when borrowers file for bankruptcy. Djankov, McLiesh, and Shleifer (2007) construct and test an international sample of 129 countries to study how financial development (measured by private credit to GDP) responds to differences in creditor laws. Their findings reveal that financial systems flourish more when the laws protecting creditors are strong, enforcement is guaranteed, and when enough credit information is available. Once again, this finding is more significant in common law than in civil law countries.

Other research, exclusively using firm-level data, focuses on the relationship between creditor institutions and banking development. These studies obtain results that are consistent with the literature explaining the institution/financial development nexus. For instance, Haselmann, Pistor, and Vig (2009); Safavian and Sharma (2007) find that creditor protection laws improve lending, reduce interest rates, and lengthen loan maturities (Qian \& Strahan, 2007). Creditor laws, registries and information sharing also improve firms' access to finance in developing countries (Peria \& Singh, 2014) as banks are likely to offer lower lending rates in an environment that is protective for lenders.

In sum, the law and finance literature suggests that countries with strong institutions that protect investors and creditors are associated with better and more efficient financial systems. Strong institutions are found to be more likely in common law countries than in civil law countries (La Porta et al., 1998). Accordingly, we propose for African countries:

Proposition 2: Legal institutions protecting investors and creditors explain the development of banking systems. The countries' legal traditions amplify this relationship.

\section{Empirical approach}

\subsection{Data}

The data comes from a variety of sources. Institutional development data, macro-economic variables, banking development, governance indicators, and population figures are all obtained from the World Bank. The data on the sub-classification of legal origins is from

Klerman, Mahoney, Spamann, and Weinstein (2011) and Oto-Peralías and Romero-Ávila (2014). In addition, we use the countries' profile of legal systems in Africa provided by 
the Lex Mundi Law Firm Network. Data pertaining to legal systems development (use of case law) is obtained from Guerriero (2016) who draws heavily on the International Encyclopedia of Comparative Law database.

The criteria for inclusion in the country sample were (1) located on the African continent and (2) is a former colony or was once occupied by a European state. We excluded North African countries since these countries experienced the influence of the Ottoman Empire, a tradition different from either civil or common law traditions. In addition, we excluded the island countries of Comoros, Seychelles and Mauritius. Although these countries were ultimately occupied by France or Britain, they already had different histories borrowed from Asian traditions. Liberia was also excluded since most of its legal tradition is borrowed from the United States of America, and originates in the period before colonization. After applying these selection criteria, our sample covers 40 African states observed over the period of 2000-2016.

\subsection{Measurement of legal systems' and financial institutions' devel- opment}

Similar to La Porta et al. (1997) and La Porta et al. (2008) we use categorial variables to indicate legal traditions. We differentiate between countries with British common law legal origin, mixed common law countries, French civil law and mixed civil law. Table 1 groups the sample countries into the four categories. To capture the type of colonization we distinguish between settler communities (Settler) and purely extractive colonization regimes (Extraction). We indicate the technique of developing the legal system by a dummy variable case law following Beck et al. (2002), Guerriero (2016) and La Porta et al. (2004). This variable measures whether courts apply legal precedents established by case law when adjusting legal systems to respond to new legal and economic circumstances. A value of 1 is assigned to those countries that use case law and zero otherwise.

Financial development institutions are drawn from the World Bank's Doing Business Reports (DBR) pertaining to minority investor and creditor protection rights. Minority investor's protection rights are measured by the Investor protection index capturing how countries' laws protect small shareholders from expropriation by block-holders and management. Creditor rights protection is measured using the index Creditor rights. This variable captures the extent to which regulation and laws protect creditors from losses arising from loan defaults (Djankov et al., 2007). Enforcing contracts measures the time that it takes creditors in a given country to enforce debt contracts. We also adopt Kaufman and Kraay (2008)'measures of countries institutional development namely: Control of corruption, and Regulatory quality. 


\subsubsection{Measurement of banking systems development}

The Global Financial Development Database (GFDD) (Demirguc-Kunt, Klapper, Singer, Ansar, \& Hess, 2018) provides the data for measuring the state of the country's banking system. The World Bank's typology comprises three characteristics, (1) banks' depth, (2) breadth, and (3) intermediation. Two ratios, the ratio of private credit provided by domestic banks to the private sector to Gross Domestic Product (GDP) (Private credit), ${ }^{1}$ and the ratio of liquid liabilities to GDP (Liquid liabilities to GDP) measure bank depth. The amount of deposit resources mobilized by banks as a percentage of a country's GDP (Deposits to GDP) represents the banking system's breadth. Two other variables, namely Loans to deposits and Net interest margins (NIM), indicate the level of bank intermediation. A higher value in one of these variables indicates a more developed banking system.

\subsection{Control variables}

We control for the macro-economic environment by using a proxy of the country's average income level, Log (GDPpercapita). The size of a country's population is also included as a control variable expressed as a natural logarithm the country's population size, denoted as $\log$ (Population). Table 2 in the Appendix provides names of the variables and their description.

\section{Analysis and Results}

\subsection{Sample description}

Table 3 summarizes means and standard deviations of the variables used. Forty percent of the sample are countries that were once French colonies and use civil law as the basis of their legal system. Countries that were colonized by other European states but still practice civil law account for $22.5 \%$ of the sample. Colonies of Great Britain practising common law account for $27.5 \%$ of the sample. Countries that were not British colonies but use common law as their legal basis make $10 \%$ of the sample. Settler colonies account for $32 \%$, while $68 \%$ belong to the extraction colonies group. Fifty-three percent of the countries use case law as a basis for legal systems development. The institutional variables

\footnotetext{
${ }^{1}$ It should be noted that, based on a sample of developed and emerging economies Cecchetti and Kharroubi (2012), find that the ratio of private sector credit to GDP is supporting economic growth only up to a certain point. Beyond that point, a high ratio is a drag on growth. Pineda (2017) argues that a rising private sector borrowing was an important ingredient for the Asian financial crisis in the most affected four developing Asian economies. Private sector borrowing became unsustainable as the value of financial and real assets deteriorated when the 1997/1998 Asian financial crisis enfolded.
} 
display the following country means: the investor protection score is 4.2 , the creditor rights score is 47.4, and it takes an average of 664 days to enforce debt contracts.

Table 3 shows the means of banking system indicators. Lending to private sector is on average $16 \%$ and liquid liabilities to GDP is $28.7 \%$. These findings closely corroborate previous results in Beck, Fuchs, Singer, and Witte (2014) that private credit and liquid liabilities to GDP are on average in Africa 18\% and 32\% respectively, compared to $34 \%$ and $47 \%$ in other developing countries outside the continent. Additionally, loans to deposits account for $71 \%$ and the net interest margin is on average $7.14 \%$. Deposits to GDP is on average $21.6 \%$. For control variables, results in Table 3 show that the average annual growth rate is $4.7 \%$, the inflation rate is at $1.67 \%$, and GDP per capita is US\$1,719. The average population size is 17.5 million.

[Table 3 here]

Tables 4 and 5 summarize the indicators of the development of banking systems by country over time. There are remarkable differences in the sample with respect to private sector lending. South Africa has the highest (above 60\%), while countries such as the Democratic Republic of Congo, Chad, Guinea and Guinea Bissau have the lowest ratio of private credit to GDP (below 10\%). A longitudinal comparison reveals that Botswana and Cape Verde show observable improvements with respect to the private credit to GDPvariable over time, while Chad, Congo and Gabon have experienced a reduction in this ratio. Tables 4 and 5 also show that some countries have banks with extremely large liquid liabilities to GDP and a larger proportion of loans to deposits. With respect to intermediation, countries such as Angola, Central African Republic, Democratic Republic of Congo, Gabon, Ghana, Liberia, Malawi, Siera Leone, Tanzania, Uganda and Zimbabwe have relatively higher interest margins.

[Table 4 here]

[Table 5 here]

Table 6 summarizes descriptive statistics for the legal origins tradition. The results show that common law countries are more likely to use case law (93\%) than civil law countries $(21 \%)$. Minority shareholders and creditors are relatively more protected in common law than in civil law countries. For banking development variables, Table 4 shows that private credit to GDP in common law countries is higher than in civil law countries. Similar findings are reported for loans to deposits, and deposits to GDP. However, common law countries are more associated with higher bank intermediation costs (NIM) than their civil counterparts. For other controls, results show that civil law countries are associated with lower GDP per capita than their common law peers.

[Table 6 here] 


\subsection{Econometric models}

Given the panel nature of our sample, two estimation techniques are employed. First, a pooled regression model is used to explain institutional development in terms of creditor and investor protection as well as in terms of enforcement of contracts. This method is chosen as it allows us to obtain the effects from time-invariant regressors that could not be identified with the fixed effects panel model. Furthermore, the pooled regression model exploits both the within and between variation for the estimation of effects. Timeinvariant legal traditions and other time-varying country controls are used as explanatory variables as shown below:

$$
\text { Creditor/Investor protection } i t=f\left(\text { Legal traditions }_{i}, \text { Controls }_{i t}\right)+\epsilon_{i t}
$$

where the dependent variables describe the institutional legal development for countries $i=1, \ldots, N$ in year $t$. The variable Legal traditions ${ }_{i}$ represents the legal origins category consisting of common law (British), common law (mixed), civil law (French) and civil law (mixed), and the type of colonization (settler versus extraction). Control ${ }_{i t}$ denotes the country controls including country's population size (using log) and macro-economic variables including growth rate and GDP per capita in country $i$ at time $t . \epsilon_{i t}$ denotes the error term.

We also employ the Hausman-Taylor (HT) estimator (Hausman \& Taylor, 1981), which is used to obtain the effects of time-invariant regressors, while at the same time allowing for country-specific unobserved heterogeneity in terms of random effects. Furthermore, the HT estimator allows us to distinguish between endogenous and exogeneous regressors, where it is assumed that endogenous regressors are correlated with the unobserved country-specific effects. The HT estimator uses the exogenous variables as instruments for the endogenous ones.

In our context, the HT estimator is applied to estimate how financial legal institutions affect the development of banking systems in the countries,

$$
\begin{aligned}
y_{i t}= & f\left(\text { Creditor rights }_{i t}, \text { Investor protection }_{i t}, \text { Enforcing Contracts }_{i t},\right. \\
& \text { Exogenous variables } \left._{i / i t}, \lambda_{t}, \mu_{i}\right)+v_{i t}
\end{aligned}
$$

where $y_{i t}$ are the indicators representing the banking system development, namely: Private credit, Loan to deposits, Deposits to GDP, Liquid liabilities to GDP, and NIM. We specify the indicators of the financial legal institutions, Creditor rights $s_{i t}$, Investor protec-

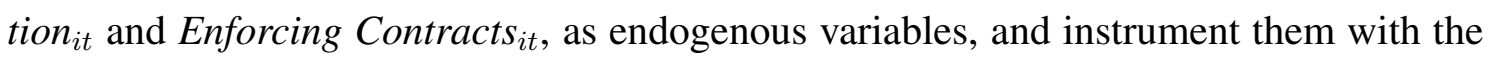
exogenous variables Legal origin, Colonization type and the two macro controls. Year 
effects are denoted as $\lambda_{t}$, country-specific effects as $\mu_{i}$ and the error term is denoted as $v_{i t}$.

In the Section 4.4, we also report results from robustness tests using a fixed-effects (FE) model. However, since legal origin variables are time-invariant, the FE model cannot identify the effect of the legal origin indicators.

\subsection{The legal and colonial heritage shapes the banking system}

\subsubsection{The relationship between legal origin and financial legal institutions}

We analyse the relationship between legal origin and financial legal institutions applying a pooled ordinary least squares (OLS) model. Table 7 reports the results. Our main interest is to examine whether the quality of the financial legal institutions is strongly linked to the legal origin. In addition, usage of case law is employed as the dependent variable. As is common in the La Porta et al. (1997; 1998) (LLSV) literature, in this specification the legal origin describes only the dichotomous categories of common and civil law. The significance of the legal origin coefficients strongly confirms Proposition 1. Common law is linked to stronger investor protection and creditor rights and to a shorter time for debt contracts to be enforced, which is not the case with civil law. Application of case law is also significantly more likely in countries from the common law origin. Not entirely surprisingly, results for the dichotomous categories of legal origin are in line with previous findings in the LLSV literature (Beck et al., 2002; Djankov et al., 2003; La Porta et al., 1997). The type of colonization (settler versus extraction) also matters. The coefficient of the variable Colonial type: settler is related to a higher level of investor protection. Interestingly, former settler colonies are associated with weaker contract enforcement mechanisms, in the sense that in those countries it takes on average more days to enforce a contract.

The other macro indicators are of minor relevance in the pooled regression approach. The level of economic development (measured by GDP per capita) has no significant impact on any of the dependent variables. The size of the country in terms of population only affects the existence of strong creditor rights positively.

\section{[Table 7 here]}

Table 8 reports results using the legal origins sub-groups as covariates in the pooled regression approach. It turns out that British common law judicial origins have stronger creditor rights and better investor protection than civil law countries. However, mixed civil law countries are only associated with a lower level of creditor rights, but are otherwise not statistically different from French civil law countries in terms of creditor rights. 
British-style common law countries have stronger creditor rights standards than civil law countries but show otherwise no deviation from mixed common law countries. One interesting difference occurs in the duration of contract enforcement, where the average number of days it takes for enforcement is 149 days less in British common law traditions than in French civil law countries. Mixed common and civil law countries are not different from French civil law countries in this respect.

Case law is more often used in both mixed common and civil law traditions than in French civil law origins. Because of perfect collinearity British common law countries drop out in the regression and no results for British common law appear in Column 4 of Table 8 . The colonial type and the other control variables yield similar results to those shown in Table 7.

[Table 8 here]

\subsubsection{Legal financial institutions and banking sector development}

We turn now to our main question of interest: How do legal financial institutions shape the evolution of banking sectors in African countries and what role does the legal and colonial heritage play? In a first step, we proceed with the pooled OLS estimator. Table 9 reports the regression results. Creditor rights and Enforcing contracts seem to influence banking system development, however, creditor rights have, in contrast to Proposition 2, a negative effect on depth and breadth of the banking system. We also find a direct and positive influence of a common law jurisdiction and a settler-type colonial history on the depth and breadth of the country's banking system. Clearly, as many coefficients of the legal financial institutions are insignificant or have an unexpected sign, the obtained results from the pooled OLS estimation do not support Proposition 2. However, Table 9 only presents a preliminary and incomplete picture. This is because the variables representing the development of financial institutions (Creditor rights, Investor protection and Enforcing contracts) are potentially endogenous in explaining the banking sector development. Accordingly, the natural next step is accounting for the endogeneity problem. We do so by applying the Hausman-Taylor (HT) estimator.

[Table 9 here]

\subsubsection{Financial institutions and banking sector development: The HT approach}

The Hausman-Taylor estimator uses instruments to explain depth, breadth and the level of intermediation in the countries' banking sectors. Specifically, we instrument Creditor rights, Investor protection and Enforcing contracts with all exogenous variables in the 
specification. By using instruments, in particular the legal origin, we follow earlier scholarly work, e.g. Levine et al. (2000), La Porta et al. (2006), Caprio et al. (2007) and Beck, Demirgüç-Kunt, and Maksimovic (2006) who use legal traditions to explain minority investor protection, creditor rights, contract enforcement and property rights. As African countries received their legal origins through colonization, the legal traditions are exogenous to the countries and their banking systems. However, they are strongly correlated with the legal financial institutions as has been shown in Tables 7 and 8 . When we include the colonial type as an instrument, we borrow from Acemoglu, Johnson, and Robinson (2001). They suggest that colonial strategies explain subsequent settlements and institutional development in the former colonies, including the achieved standards in investor and property rights institutions.

Tables 10 and 11 display the evidence obtained with the Hausman-Taylor panel estimator. Using instruments change the results considerably but overall the support for Proposition 2 remains still quite weak. We find, however, that an increase in the level of creditor rights reduces the interest rate margin. This may be a sign for a lower lending risk premia because of banks strong position as a creditor.

Furthermore, investor protection laws do not significantly improve private credit and actually lowers the ratio of liquid liabilities to GDP and of deposits to GDP. Strong debt contract enforcement is not relevant for the development of the banking system. Banks in common law countries have more trust in private credit, and collect more deposits as a share of GDP than banks in civil law jurisdictions. Despite stronger capital market financing in common law jurisdictions, the importance of lending out of deposits is similar in both common and civil law jurisdictions. Naturally, countries of the settler colonial type have deeper and broader financial systems than countries in which pure extraction was common. This is compatible with the notion that, in contrast to the native population, settlers had the power to influence political and judicial decision making in support of constructing and developing a decent banking system in the colonies. Taken together, the evidence does not provide much support for Proposition 2. While legal origin matters, current legal financial institutions show only a modest impact on banking system development in African countries.

\section{[Table 10 here]}

Dividing the legal heritage into four groups confirms the results for the instrumented legal financial institutions indicators. At the same time it yields a more detailed picture about how legal heritage and the type of colonization affect banking system development. In terms of financial development (depth) it is the mixed common law countries that differ from all other legal heritage groups (including the British common law countries). The mixed common countries employ more private credit and have higher levels of liquid 
liabilities relative to GDP. Higher private credit is also associated with the settler-type colonization. Interestingly, only the mixed common law tradition has a statistically distinguishable effect on the level of intermediation vìs-à-vìs the civil law tradition. The cost of banking is significantly higher in British common law countries, again hinting at a priority for capital market financing in those jurisdictions.

Jurisdictions that use case law to evolve their legal precedent show a better ability to convert deposits into loans than non-case law countries. Table 11 also shows that the size of the population is irrelevant for the development of the banking system. However, the depth and breadth of the banking system is lower in more wealthy countries. The latter finding is consistent with the conjecture that in high income countries, capital markets become relatively more important.

\section{[Table 11 here]}

Our final set of estimates describes the role of institutional and regulatory quality on the development of banking systems in African countries. Specifically, we employ the variables Regulatory quality and Control of corruption as measures for the overall institutional quality in the respective country. The Hausman-Taylor estimation results shown in Table 12 highlight that institutional quality matters for all dimensions of banking system development, and even renders some of the previously significant factors as insignificant. Specifically, we find that the effect of common law origin becomes insignificant for private credit and cost of banking (proxied by NIM), once the variables that capture institutional and regulatory quality are included in the specification. Note that, in contrast, the effect from the Colonization type remains significant both for private loans and for bank deposits. This shows that the positive effect on financial development from having a legal system embedded in common law tradition also captures the higher institutional quality in those countries. Interestingly, the direct measure of using case law has no significant effect in most estimations. Thus, it is not the utilization of case law in common or civil law countries that matters, but a higher institutional and regulatory quality that is conducive for banking system development.

[Table 12 here]

\subsection{Robustness tests}

The FE model is unable to capture the effect of the legal origin variables as they are time-invariant. Therefore, we run fixed effects models only as a test for the robustness of the Hausman-Taylor results. Note that the FE models allow for correlation between the right-hand side variables and unobserved heterogeneity across countries. Furthermore, 
the effects of variables are identified from the within-country variation, while the HT estimation also captures cross-country variation.

Tables 13 and 14 show that the main conclusion regarding the low impact of the current financial legal institutions on the developmental stage of the banking systems also hold in the FE specification. Table 14 confirms that institutional and regulatory quality has a significant impact on banking system development.

Second, we split the sample into four subsamples following the legal origins classification and rerun the estimations. By and large the results are consistent with the findings in the main specification. ${ }^{2}$ Specifically, the robustness test confirms that countries using civil law as a legal regime tend to have low investor protection standards, and a financial system with shallow depth and breadth.

Finally, we test the influence of the 2008 financial crisis on our main findings. For this purpose, we construct two samples covering the period before 2008 and the period from 2008 to 2016 and rerun the HT estimations again. Results for the period up to 2008 show that only the variable for the days required to enforce debt contract affects significantly banking system development. Creditor rights do lower the cost of bank intermediation, but have no impact on the depth and breadth of the banking system. This is different in the post-crisis period during which the creditor rights variable turns out to predict significantly banking system development (depth, breadth and intermediation), while the coefficients of the covariates, Investor protection and Enforcing contracts remain insignificant. This finding may indicate that the authorities in the countries included in our sample responded to the financial crisis by strengthening the rights of creditors.

\section{Conclusions}

The law and finance literature claims that legal traditions explain the development of legal systems, institutions and financial systems. This study examines whether this claim holds for banking system development in African countries. In addition, we hypothesize that not only is the legal heritage important, but the type of also colonization matters. We use a sample of 40 African countries and focus exclusively on banking system development instead of considering the entire financial system, as is commonly done in extant literature.

As expected, we find confirmation for the legal traditional channel, and show that a common law heritage leads to stronger legal financial institutions (Proposition 1). Surprisingly, however, we find little evidence that the second expected channel of stronger

\footnotetext{
${ }^{2}$ The Tables using subsamples of legal origin and pre- and post financial crisis are not reported but are available from the authors upon request.
} 
legal financial institutions leads to a more highly developed banking system (Proposition 2). Despite this, one finding that emerges is that stronger creditor rights reduce the cost of banking in African countries.

Overall, our study confirms the conjecture that legal history matters for the quality of current institutions in African countries, and that both the legal origin and the type of colonization determine the strength of current legal financial institutions, e.g., creditor rights and investor protection. The results also highlight that institutional and regulatory quality significantly promotes banking system development in African countries. Whether or not current institutional quality itself is related to the legal origin and colonial history is a question left for future research.

These findings have important policy implications. Although the law and finance literature concludes that there are differences in financial outcomes from the two legal traditions with the emphasis on the superiority of the common law tradition, findings from our study indicate that the quality of institutions that emerge from these legal systems matter for banking system development in Africa in both civil and common law traditions. Our results indicate that policy makers and regulators would do well to pay less attention to strengthening the existing legal financial institutions, e.g., creditor rights or investor protection, but rather focus on improving the overall institutional and regulatory quality in order to promote banking system development.

\section{References}

Acemoglu, D., Johnson, S., \& Robinson, J. A. (2001). The colonial origins of comparative development: An empirical investigation. American Economic Review, 91(5), 1369-1401.

Aluko, O. A., \& Ajayi, M. A. (2018). Determinants of banking sector development: Evidence from Sub-saharan African countries. Borsa Istanbul Review, 18(2), 122139.

Andrianaivo, M., \& Yartey, C. A. (2010). Understanding the growth of African financial markets. African Development Review, 22(3), 394-418.

Beck, T., \& Cull, R. (2014). Banking in Africa. In The oxford handbook of banking, second edition.

Beck, T., Demirgüç-Kunt, A., \& Levine, R. (2003). Law and finance: why does legal origin matter? Journal of Comparative Economics, 31(4), 653-675.

Beck, T., Demirgüç-Kunt, A., \& Maksimovic, V. (2006). The influence of financial and legal institutions on firm size. Journal of Banking \& Finance, 30(11), 2995-3015. 
Beck, T., Demirguc-Kunt, A., et al. (2005). Law and firms' access to finance. American Law and Economics Review, 7(1), 211-252.

Beck, T., Fuchs, M., Singer, D., \& Witte, M. (2014). Making cross-border banking work for Africa. Eschborn, Germany: Deutsche Gesellschaft für Internationale Zusammenarbeit (GIZ) GmbH.

Beck, T., \& Levine, R. (2005). Legal institutions and financial development. In Handbook of new institutional economics (pp. 251-278). Springer.

Beck, T., Levine, R., \& Demirgüç-Kunt, A. (2002). Law and finance: why does legal origin matter? The World Bank.

Beck, T., Maimbo, S. M., Faye, I., \& Triki, T. (2011). Financing Africa: Through the crisis and beyond. The World Bank.

Caprio, Laeven, L., \& Levine, R. . (2007). Governance and bank valuation. Journal of Financial Intermediation, 16(4), 584-617.

Cecchetti, S., \& Kharroubi, E. (2012). Reassessing the impact of finance on growth (BIS Working Papers No. 381). Bank for International Settlements. Retrieved from https://EconPapers.repec.org/RePEc:bis:biswps:381

Demirguc-Kunt, A., Klapper, L., Singer, D., Ansar, S., \& Hess, J. (2018). The global findex database 2017: Measuring financial inclusion and the fintech revolution. The World Bank.

Djankov, S., Glaeser, E., La Porta, R., Lopez-de Silanes, F., \& Shleifer, A. (2003). The new comparative economics. Journal of Comparative Economics, 31(4), 595-619.

Djankov, S., La Porta, R., Lopez-de Silanes, F., \& Shleifer, A. (2008). The law and economics of self-dealing. Journal of Financial Economics, 88(3), 430-465.

Djankov, S., McLiesh, C., \& Shleifer, A. (2007). Private credit in 129 countries. Journal of Financial Economics, 84(2), 299-329.

Emenalo, C. O., Gagliardi, F., \& Hodgson, G. M. (2018). Historical institutional determinants of financial system development in africa. Journal of Institutional Economics, 14(2), 345-372.

Guerriero, C. (2016). Endogenous legal traditions. International Review of Law and Economics, 46, 49-69.

Haselmann, R., Pistor, K., \& Vig, V. (2009). How law affects lending. The Review of Financial Studies, 23(2), 549-580.

Hausman, J., \& Taylor, W. (1981). Panel data and unobservable individual effects. Econometrica, 49(6), 1377-98. Retrieved from https://EconPapers.repec.org/RePEc:ecm: emetrp:v:49:y:1981:i:6:p:1377-98

Kaufman, D., \& Kraay, A. (2008). Governance indicators: Where are we. Where Should We Be Going. 
Klerman, D. M., Mahoney, P. G., Spamann, H., \& Weinstein, M. I. (2011). Legal origin or colonial history? Journal of Legal Analysis, 3(2), 379-409.

La Porta, R., Lopez-de Silanes, F., Pop-Eleches, C., \& Shleifer, A. (2004). Judicial checks and balances. Journal of Political Economy, 112(2), 445-470.

La Porta, R., Lopez-de Silanes, F., \& Shleifer, A. (2006). What works in securities laws? The Journal of Finance, 61(1), 1-32.

La Porta, R., Lopez-de Silanes, F., \& Shleifer, A. (2008). The economic consequences of legal origins. Journal of Economic Literature, 46(2), 285-332.

La Porta, R., Lopez-de Silanes, F., Shleifer, A., \& Vishny, R. W. (1997). Legal determinants of external finance. The Journal of Finance, 52(3), 1131-1150.

La Porta, R., Lopez-de Silanes, F., Shleifer, A., \& Vishny, R. W. (1998). Law and finance. Journal of Political Economy, 106(6), 1113-1155.

Levine, R. (1998). The legal environment, banks, and long-run economic growth. Journal of Money, Credit and Banking, 596-613.

Levine, R., Loayza, N., \& Beck, T. (2000). Financial intermediation and growth: Causality and causes. Journal of Monetary Economics, 46(1), 31-77.

Maoz, Z., \& Henderson, E. A. (2013). The world religion dataset, 1945-2010: Logic, estimates, and trends. International Interactions, 39(3), 265-291.

Mlachila, Cui, L., Jidoud, A., Newiak, M., Radzewicz-Bak, B., Takebe, M., ... Zhang, J. (2016). Financial development in Sub-Saharan Africa: promoting inclusive and sustainable growth (Tech. Rep.). International Monetary Fund.

Mutarindwa, S. (2019). Institutions, regulations, performance and stability of African banks. Jönköping University, Jönköping International Business School, ISSN: 1403-0470, series no 130. ( $\mathrm{PhD}$ thesis)

Oto-Peralías, D., \& Romero-Ávila, D. (2014). The distribution of legal traditions around the world: a contribution to the legal-origins theory. The Journal of Law and Economics, 57(3), 561-628.

Peria, M. S. M., \& Singh, S. (2014). The impact of credit information sharing reforms on firm financing. The World Bank.

Pineda, P. (2017). Financial liberalization and private sector borrowing in Asean 4 economies 1990-2012. Eurasian Economic Review, 7(2), 277-295. Retrieved from https://doi.org/10.1007/s40822-017-0066-0

Porta, R. L., Lopez-de Silane, F., Pop-Eleches, C., \& Shleifer, A. (2002). The guarantees of freedom (Tech. Rep.). National Bureau of Economic Research.

Qian, J., \& Strahan, P. E. (2007). How laws and institutions shape financial contracts: The case of bank loans. The Journal of Finance, 62(6), 2803-2834.

Safavian, M., \& Sharma, S. (2007). When do creditor rights work? Journal of Compar- 
ative Economics, 35(3), 484-508. 
Appendices

Tables 
Table 1: Legal traditions classifications

\begin{tabular}{llll}
\hline Civil-French & Civil-mixed & Common-British & Common-Mixed \\
\hline Benin & Angola (Portugual) & Gambia & Botswana (British+ Dutch) \\
Burkina Faso & Burundi (Belgium) & Ghana & Namibia (British + Dutch) \\
Cameroon & Cape Verde (Portugual) & Kenya & South Africa (British + Dutch) \\
Central African Rep. & Democratic Rep. of Congo (Belgium) & Lesotho & Swaziland* (British + Dutch) \\
Chad & Equaterial Guinea (Spain) & Malawi & Zimbabwe (British + Dutch) \\
Cote d'Ivoire & Eritrea (Italy) & Nigeria & \\
Djibouti & Guinea Bissau (Portugual) & Sierra Leone & \\
Gabon & Mozambique (Portugual) & Tanzania & \\
Guinea-Conakry & Rwanda (Belgium) & Uganda & \\
Madagascar & & Zambia & \\
Mali & & & \\
Mauritania & & & \\
Niger & & & \\
Senegal & & & \\
Togo & & & \\
\hline
\end{tabular}

Source: Oto-Peralías and Romero-Ávila (2014); Klerman et al. (2011) and, Lex Mundi. Swaziland changed its name in 2018 to Eswatini. 
Table 2: Variables description

\begin{tabular}{|c|c|c|}
\hline Variable & Descriptions & Source \\
\hline Case law & $\begin{array}{l}\text { A dummy variable with the value } 1 \text { if a country uses case law in } \\
\text { its judicial processes and decisions; and } 0 \text { otherwise. }\end{array}$ & (c) \\
\hline Civil law (French) & $\begin{array}{l}\text { Dummy variable with the value } 1 \text { if the country was a direct } \\
\text { French colony; and } 0 \text { otherwise. }\end{array}$ & (b) \\
\hline Civil law (mixed) & $\begin{array}{l}\text { Dummy variable with the value } 1 \text { if the country uses civil-law but } \\
\text { not formerly colonized by France; and } 0 \text { otherwise. }\end{array}$ & (b) \\
\hline Colonial type & $\begin{array}{l}\text { Dummy variable for colonization approaches with the value } 1 \text { if } \\
\text { the country was a settler colony; and } 0 \text { if the country was an ex- } \\
\text { traction colony. }\end{array}$ & (b) \\
\hline Common law (British) & $\begin{array}{l}\text { Dummy variable with the value } 1 \text { if the country is a direct British } \\
\text { colony; and } 0 \text { if a country was colonized by a country using } \\
\text { British common law. }\end{array}$ & (b) \\
\hline Common law (mixed) & $\begin{array}{l}\text { Dummy variable with the value } 1 \text { if the country uses common-law } \\
\text { but not formerly colonized by Britain; and } 0 \text { otherwise. }\end{array}$ & (b) \\
\hline Control of corruption & $\begin{array}{l}\text { A measure of the extent to which politicians and policy makers } \\
\text { use their power and influence for private gains and measured us- } \\
\text { ing a scale from }-2.5 \text { to }+2.5 \text {. }\end{array}$ & (a5) \\
\hline Creditor rights & $\begin{array}{l}\text { Assesses the extent to which credit laws protect both lenders and } \\
\text { borrowers to simplify lending, and is measured on a scale of } 1 \text { to } \\
10 \text {, where } 10 \text { is the highest score. }\end{array}$ & (a2) \\
\hline Deposits to GDP & $\begin{array}{l}\text { This measures banks' customer deposits as a percentage of a } \\
\text { country's GDP. }\end{array}$ & (a1) \\
\hline Enforcing contracts & Measured in number of days required to enforce contracts. & (a2) \\
\hline Investor protection & $\begin{array}{l}\text { A composite of measures showing the extent to which minority } \\
\text { investors are protected from expropriation with the value of } 1 \text { for } \\
\text { the weakest and } 10 \text { the strongest. }\end{array}$ & (a2) \\
\hline Liquid liabilities to GDP & $\begin{array}{l}\text { Liquid, currency, demand and interest-bearing liabilities a per- } \\
\text { centage of a country' GDP }\end{array}$ & (a1) \\
\hline Loans to deposits & Ratio of lending size to total bank deposits. & (a1) \\
\hline Log (GDPpercapita) & $\begin{array}{l}\text { Gross domestic product per capita population, expressed in natu- } \\
\text { ral logarithm form. }\end{array}$ & (a3) \\
\hline Log (Population) & $\begin{array}{l}\text { Population size of a given country and expressed in natural loga- } \\
\text { rithm form. }\end{array}$ & (a4) \\
\hline NIM & $\begin{array}{l}\text { Net interest margin is a measure of the difference between bank } \\
\text { interest income and interest expenses. It is expressed as a per- } \\
\text { centage. }\end{array}$ & (a1) \\
\hline
\end{tabular}


...continued

\begin{tabular}{lll}
\hline Variable & Descriptions & Source \\
\hline Private credit to GDP & Loans to private sector as a percentage of GDP. & (a1) \\
Regulatory quality & A measure of the extent to which states and governments are able & (a5) \\
& to develop and execute policies that incentivize private sector de- \\
& velopment measured on a scale of -2-5 to +2.5. & \\
\hline
\end{tabular}

Notes: Sources (a1) Global Financial Development Database; (a2) Doing Business projects; (a3) World

Development Indicators; (a4) World Population estimates; (a5) World Governance Indicators (b) Maoz and Henderson (2013) Klerman et al. (2011); La Porta et al. (1997); Oto-Peralías and Romero-Ávila (2014); (c)

Guerriero (2016) 
Table 3: Descriptive statistics (country-year observations)

\begin{tabular}{lrrrrr}
\hline Variable & Obs & Mean & Std. Dev. & \multicolumn{1}{c}{ Min } & \multicolumn{1}{c}{ Max } \\
\hline Bank credit to deposits & 661 & 71.34 & 26.81 & 13.75 & 164.6 \\
Bank deposits to GDP & 636 & 21.57 & 15.96 & 0.93 & 93.3 \\
Case law & 577 & 0.530 & 0.500 & 0 & 1 \\
Civil law-French & 679 & 0.400 & 0.490 & 0 & 1 \\
Civil law-Mixed & 679 & 0.225 & 0.418 & 0 & 1 \\
Colonial type (Settler type) & 679 & 0.325 & 0.469 & 0 & 1 \\
Common law-British & 679 & 0.275 & 0.447 & 0 & 1 \\
Common law-Mixed & 679 & 0.100 & 0.300 & 0 & 1 \\
Control of corruption & 601 & -0.570 & 0.617 & -1.84 & 2 \\
Creditor rights & 384 & 47.4 & 22.61 & 10 & 100 \\
Enforcing contracts & 496 & 663 & 279 & 230 & 1785 \\
Investor protection & 374 & 4.195 & 1.382 & 2 & 8 \\
Legal origins & 680 & 0.375 & 0.484 & 0 & 1 \\
Liquid liabilities to GDP & 651 & 28.72 & 21.1 & 1.53 & 137.7 \\
Population (in million) & 674 & 17.5 & 26.3 & 0.438 & 190 \\
GDPpercapita & 674 & 1,719 & 2,763 & 113 & 22,942 \\
NIM & 609 & 7.14 & 3.25 & 0.03 & 23.32 \\
Private credit & 658 & 16.20 & 14.23 & 0.33 & 128.6 \\
Regulatory quality & 640 & -0.650 & 0.565 & -2.261 & 0.791 \\
\hline
\end{tabular}


Table 4: Banking system development indicators by country (2000 and 2010)

\begin{tabular}{|c|c|c|c|c|c|c|c|c|c|c|}
\hline \multirow[b]{2}{*}{ Country } & \multicolumn{5}{|c|}{2000} & \multicolumn{5}{|c|}{2010} \\
\hline & (1) & (2) & (3) & (4) & (5) & (1) & (2) & (3) & (4) & (5) \\
\hline Angola & 1.1 & 10.2 & 8.3 & 13.8 & 3.5 & 18.7 & 32.3 & 29.8 & 62.6 & 7.22 \\
\hline Benin & 9.8 & 23.6 & 13.1 & 74.8 & 4.1 & 21 & 35.5 & 25.3 & 83.0 & 3.78 \\
\hline Botswana & 13.4 & 24.9 & 22.9 & 58.6 & 6.6 & 25.9 & 47.3 & 44.9 & 57.8 & 5.8 \\
\hline Burkina Faso & 10.7 & 20.1 & 12.2 & 87.9 & 4.8 & 16.2 & 25.8 & 20.4 & 79.2 & 3.9 \\
\hline Burundi & 14.1 & 16.3 & 10.9 & 129.9 & 11.7 & 15.4 & 25.0 & 19.5 & 78.9 & 5.2 \\
\hline Cameroon & 7.7 & 13.9 & 10.1 & 76.7 & 3.9 & 10.5 & 21.0 & 16.9 & 62.2 & 5.2 \\
\hline Cape Verde & 34.3 & 55.0 & 46.2 & 74.2 & - & 58.6 & 78.2 & 72.2 & 81.2 & 4.9 \\
\hline Central African & - & - & - & - & - & 7.6 & 17.1 & 8.3 & 90.6 & 8.1 \\
\hline Chad & 3.0 & 9.8 & 3.2 & 94.4 & 7.5 & 3.7 & 10.4 & 4.5 & 82.4 & 5.4 \\
\hline Congo Republic & 5.7 & 11.8 & 6.5 & 87.7 & - & 4.4 & 19.9 & 12.5 & 35.2 & 2.9 \\
\hline Côte d'Ivoire & 14.8 & 22.1 & 13.8 & 107.2 & 5.4 & 15.8 & 30.9 & 18.7 & 84.3 & 4.1 \\
\hline Democratic Rep of Congo & 0.3 & 1.5 & 0.9 & 35.2 & - & 3.4 & 8.13 & 6.0 & 56.1 & 10.1 \\
\hline Djibouti & 29.9 & 53.1 & 43.7 & 68.3 & 5.5 & 31 & 90.8 & 80.6 & 38.4 & 3.7 \\
\hline Equatorial Guinea & 3.0 & 5.1 & 3.4 & 86.8 & - & 5.88 & 10.8 & 9.0 & 65.7 & 4.4 \\
\hline Eritrea & 26.5 & 130.8 & 0.0 & 24.4 & - & 14.4 & 115 & 0 & 15.6 & . \\
\hline Gabon & 7.8 & 12.7 & 9.8 & 80.1 & 5.2 & 7.4 & 18.0 & 14.5 & 51.3 & 7.8 \\
\hline Gambia, The & 8.0 & 22.2 & 16.3 & 49.1 & 6.9 & 14.8 & 47 & 39.3 & 37.5 & 8.6 \\
\hline Ghana & 7.2 & 14.3 & 8.8 & 81.7 & 8.9 & 13.8 & 26.6 & 20.7 & 66.5 & 12.0 \\
\hline Guinea & 2.7 & 8.7 & 3.8 & 72.2 & 11.0 & 3.0 & 19.8 & 11.7 & 25.3 & 4.0 \\
\hline Guinea Bissau & 4.5 & 21.7 & 7.6 & 59.8 & & 5.7 & 25.5 & 11.1 & 51.4 & 5.1 \\
\hline Kenya & 23.0 & 31.4 & 26.3 & 87.4 & 6.5 & 24.6 & 36.3 & 32.6 & 75.5 & 8.2 \\
\hline Lesotho & 13.4 & 27.5 & 25.0 & 53.4 & 16.1 & 10.4 & 30.5 & 28.5 & 36.6 & 7.9 \\
\hline Madagascar & 8.0 & 24.8 & 13.0 & 61.6 & 7.3 & 11.1 & 22.4 & 16.4 & 67.7 & 4.6 \\
\hline Malawi & 2.6 & 8.6 & 6.6 & 39.5 & 12.9 & 11.3 & 19.2 & 16.5 & 68.9 & 11.9 \\
\hline Mali & 13.5 & 18.3 & 11.8 & 114.3 & 6.8 & 15.0 & 23.1 & 17.2 & 87.3 & 4.2 \\
\hline Mauritania & - & - & - & - & 9.9 & 20.9 & 24.5 & 17.4 & 120.6 & 4.3 \\
\hline Mozambique & 13.2 & 20.9 & 17.5 & 75.7 & 5.9 & 21.7 & 35.1 & 30.4 & 71.3 & 7.0 \\
\hline Namibia & 36.9 & 37.7 & 36.0 & 102.6 & 11.3 & 46.3 & 60.7 & 59.1 & 78.3 & 5.1 \\
\hline Niger & 4.6 & 8.4 & 5.4 & 85.2 & 4.0 & 11.5 & 18.3 & 10.8 & 106 & 5.1 \\
\hline Nigeria & 7.5 & 12.7 & 9.1 & 82.4 & 10.6 & 16.6 & 20.5 & 17.5 & 94.9 & 6.7 \\
\hline Rwanda & 9.5 & 15.7 & 12.1 & 78.8 & 14.2 & 11.1 & 14.8 & 12.4 & 89.4 & 8.8 \\
\hline Senegal & 16.5 & 22.5 & 17.1 & 96.5 & 6.3 & 24.4 & 37.2 & 28.8 & 84.7 & 5.5 \\
\hline Sierra Leone & 1.3 & 10.6 & 5.9 & 22.5 & 18.6 & 6.8 & 19.3 & 14.1 & 47.9 & 11.2 \\
\hline
\end{tabular}




\begin{tabular}{lrrrrrrrrrr} 
South Africa & 63.3 & 51.4 & 48.9 & 129.6 & 3.8 & 69.6 & 40.2 & 57.4 & 121.3 & 3.0 \\
Swaziland & 10.7 & 18.3 & 16.6 & 64.7 & 6.5 & 19.0 & 24.5 & 23.4 & 81.1 & 6.3 \\
Tanzania & 3.2 & 13.6 & 9.4 & 34.6 & 9.6 & 10.8 & 22.7 & 18.6 & 57.7 & 5.8 \\
Togo & 16.1 & 25.3 & 15.3 & 105.5 & 4.7 & 20.2 & 41.2 & 30.7 & 65.8 & 3.9 \\
Uganda & 5.1 & 13.8 & 10.3 & 48.9 & 13.4 & 10.5 & 18.1 & 14.6 & 72.0 & 8.6 \\
Zambia & 6.7 & 18.9 & 16.3 & 38.9 & 6.7 & 8.6 & 16.4 & 14.4 & 59.7 & 9.9 \\
Zimbabwe & 0.5 & 27.5 & 16.5 & 95.3 & 16.5 & 11.4 & - & - & 64.3 & 10.7 \\
\hline Total & 15.1 & 28.8 & 20.3 & 73.3 & 7.5 & 20.2 & 37.0 & 29.4 & 67.9 & 6.1 \\
\hline
\end{tabular}

Notes: (1) Private credit to GDP, (2) Liquid liabilities to GDP, (3) Deposits to GDP, (4) Loans to deposits, (5) NIM. 
Table 5: Banking system development indicators (2016)

\begin{tabular}{|c|c|c|c|c|c|}
\hline Country & (1) & (2) & $\begin{array}{l}2016 \\
(3)\end{array}$ & (4) & (5) \\
\hline Angola & 22.4 & 40.8 & 38.2 & 58.8 & 6.0 \\
\hline Benin & 21.2 & 42.0 & 30.7 & 69.2 & 1.7 \\
\hline Botswana & 30.4 & 40.6 & 39.6 & 76.9 & 5.3 \\
\hline Burkina Faso & 26.6 & 35.2 & 31.0 & 85.7 & 2.2 \\
\hline Burundi & 15.1 & 21.3 & 17.0 & 88.8 & 9.3 \\
\hline Cameroon & 16.4 & 22.2 & 17.2 & 95.9 & 4.0 \\
\hline Cape Verde & 59.9 & 98.9 & 93.3 & 64.2 & 3.1 \\
\hline Central African Republic & - & - & - & - & 4.8 \\
\hline Chad & - & - & - & - & 8.2 \\
\hline Congo Republic & - & - & - & - & \\
\hline Cote & 22.0 & 36.6 & 25.9 & 85.0 & 2.9 \\
\hline Democratic Rep of Congo & 5.7 & 11.0 & 8.9 & 64.1 & 6.6 \\
\hline Djibouti & 27.7 & 87.2 & 77.7 & 35.6 & 2.0 \\
\hline Equaterial Guinea & 18.7 & 21.2 & 17.8 & 104.7 & \\
\hline Eritrea & - & - & - & - & \\
\hline Gabon & 14.3 & 25.0 & 20.1 & 71.3 & 10.3 \\
\hline Gambia, The & - & - & - & - & 9.6 \\
\hline Ghana & 17.8 & 32.1 & 25.5 & 69.6 & 11.9 \\
\hline Guinea & 9.6 & 24.8 & 16.7 & 57.7 & 9.8 \\
\hline Guinea-Bissau & 7.8 & 47.0 & 16.5 & 47.6 & 2.3 \\
\hline Kenya & 31.3 & 37.9 & 34.3 & 91.4 & 9.0 \\
\hline Lesotho & 16.7 & 30.1 & 27.0 & 62.1 & 9.9 \\
\hline Madagascar & 12.5 & 20.8 & 17.4 & 72.2 & 7.9 \\
\hline Malawi & 10.0 & 20.9 & 17.7 & 56.5 & 12.8 \\
\hline Mali & 22.6 & 26.9 & 21.8 & 103.9 & 2.7 \\
\hline Mauritania & - & - & - & - & 3.5 \\
\hline Mozambique & 31.8 & 50.6 & 45.5 & 69.9 & 6.2 \\
\hline Namibia & 51.8 & 47.1 & 51.1 & 101.4 & 5.0 \\
\hline Niger & 14.8 & 26.6 & 13.7 & 107.6 & 4.3 \\
\hline Nigeria & 14.7 & 19.5 & 17.3 & 84.9 & 5.6 \\
\hline Rwanda & 19.7 & 20.0 & 17.8 & 110.7 & 8.8 \\
\hline Senegal & 31.8 & 46.1 & 36.2 & 87.9 & 3.4 \\
\hline Sierra Leone & 5.1 & 23.3 & 18.3 & 27.7 & 2.5 \\
\hline South Africa & 66.1 & 43.1 & 59.5 & 111.0 & 3.5 \\
\hline Swaziland & 20.4 & 27.2 & 25.8 & 78.9 & 6.9 \\
\hline
\end{tabular}




\begin{tabular}{lrrrrr} 
Tanzania & 13.7 & 21.8 & 17.6 & 77.9 & 10.1 \\
Togo & 36.4 & 52.5 & 42.8 & 85.2 & 2.0 \\
Uganda & 13.4 & 16.0 & 16.9 & 79.3 & 10.2 \\
Zambia & 12.7 & 18.2 & 19.1 & 66.7 & 9.6 \\
Zimbabwe & 22.0 & 32.1 & 31.5 & 69.7 & 6.4 \\
\hline Total & 27.3 & 48.0 & 39.6 & 75.1 & 6.1 \\
\hline
\end{tabular}

Notes: (1) Private credit to GDP, (2) Liquid liabilities to GDP, (3) Deposits to GDP, (4) Loans to deposits; (5) NIM. 
Table 6: Descriptive statistics by legal family of origin, country-year observations

\begin{tabular}{lrrrrl}
\hline Variable & Obs. & Civil & Common & Total & $t$-test \\
\hline Case law & 577 & 0.21 & 0.93 & 0.53 & $-24.77^{* * *}$ \\
Control of corruption & 793 & -0.36 & -0.32 & -0.24 & $-3.11^{* * *}$ \\
Creditor rights & 501 & 5.2 & 7.4 & 6.06 & $-11.33^{* * *}$ \\
Deposits to GDP & 799 & 25.7 & 29.3 & 27.1 & $-2.24^{* *}$ \\
Enforcing contracts (days) & 603 & 699 & 646 & 680 & $2.33^{* * *}$ \\
Growth rate & 660 & 4.80 & 4.65 & 4.68 & 0.13 \\
Inflation & 616 & 8.79 & 7.99 & 0.98 & 0.38 \\
Investor protection & 466 & 3.56 & 5.17 & 4.15 & $-13.7^{* * *}$ \\
Log (GDPpercapita) & 674 & 6.67 & 7.03 & 6.81 & $-4.45^{* * *}$ \\
Log (Population) & 674 & 15.7 & 16.2 & 15.9 & $-4.08^{* * *}$ \\
Liquid liabilities to GDP & 814 & 36.4 & 32.4 & 34.9 & $2.05^{* *}$ \\
Loans to deposits & 827 & 71.7 & 67.4 & 70.0 & $2.15^{* *}$ \\
NIM & 751 & 5.46 & 8.06 & 6.52 & $-11.05^{* * *}$ \\
Private credit to GDP & 822 & 18.2 & 21.5 & 19.5 & $-2.53^{* * *}$ \\
Regulatory quality & 793 & -0.8 & -0.448 & $0-.66$ & $-8.31^{* *}$ \\
\hline
\end{tabular}

Notes: ${ }^{*} p<0.10,{ }^{* *} p<0.05,{ }^{* * *} p<0.01$ 
Table 7: Relationship between legal origins, case law and investor/creditor protection (pooled regressions)

\begin{tabular}{lcccc}
\hline & $\begin{array}{c}(1) \\
\text { Creditor } \\
\text { rights }\end{array}$ & $\begin{array}{c}(2) \\
\text { Investor } \\
\text { protection }\end{array}$ & $\begin{array}{c}(3) \\
\text { Enforcing } \\
\text { contracts (days) }\end{array}$ & $\begin{array}{c}(4) \\
\text { Case } \\
\text { law }\end{array}$ \\
\hline Legal origin: common law & $33.50^{* * *}$ & $1.374^{* * *}$ & $-162.7^{* *}$ & $2.579^{* * *}$ \\
& $(9.76)$ & $(4.01)$ & $(-2.35)$ & $(3.81)$ \\
Colonial type: settler & 2.890 & $0.773^{* *}$ & $225.9^{* * *}$ & -0.668 \\
& $(0.61)$ & $(2.07)$ & $(3.19)$ & $(-1.01)$ \\
Log (GDPpercapita) & 1.467 & 0.0981 & -20.77 & 0.270 \\
& $(0.64)$ & $(0.43)$ & $(-0.39)$ & $(0.66)$ \\
Log (Population) & $3.518^{* *}$ & 0.229 & -50.73 & 0.311 \\
Cons & $(2.19)$ & $(1.38)$ & $(-1.07)$ & $(1.38)$ \\
& -31.95 & -0.842 & 1605.7 & -7.344 \\
Year effects & $(-0.91)$ & $(-0.22)$ & $(1.51)$ & $(-1.44)$ \\
Country effects & Yes & Yes & Yes & Yes \\
\hline $\mathrm{N}$ & $\mathrm{No}$ & No & No & No \\
No. countries & 380 & 371 & 491 & 577 \\
$\mathrm{R}^{2}$ & 40 & 40 & 40 & 34 \\
\hline
\end{tabular}

Notes: Cluster robust $t$ statistics in parentheses. ${ }^{*} p<0.10,{ }^{* *} p<0.05,{ }^{* * *} p<0.01$. Models (1)-(3) are based on pooled OLS, (4) is based on a pooled probit model. Reference categories: Legal origin: Civil law (French), Colonial type: extraction, Case law $=$ no. 
Table 8: Relationship between differentiated legal origins, case law and investor/creditor protection (pooled regressions)

\begin{tabular}{lcccc}
\hline & $\begin{array}{c}(1) \\
\text { Creditor } \\
\text { rights }\end{array}$ & $\begin{array}{c}(2) \\
\text { Investor } \\
\text { protection }\end{array}$ & $\begin{array}{c}(3) \\
\text { Enforcing } \\
\text { contracts (days) }\end{array}$ & $\begin{array}{c}\text { Case } \\
\text { law }\end{array}$ \\
\hline Common law: British & $34.94^{* * *}$ & $1.613^{* * *}$ & $-149.1^{* *}$ & - \\
& $(8.34)$ & $(4.43)$ & $(-2.45)$ & - \\
Common law: mixed & $24.74^{* * *}$ & $1.576^{* *}$ & -41.95 & $2.102^{*}$ \\
& $(6.32)$ & $(2.19)$ & $(-0.26)$ & $(1.73)$ \\
Civil law: mixed & -2.567 & $0.688^{*}$ & 110.4 & $1.289^{* *}$ \\
& $(-0.65)$ & $(1.80)$ & $(0.75)$ & $(2.00)$ \\
Colonial type: settler & 3.340 & $0.771^{*}$ & $220.3^{* * *}$ & -0.894 \\
& $(0.74)$ & $(1.92)$ & $(3.14)$ & $(-1.08)$ \\
Log (GDPpercapita) & 2.820 & 0.0949 & -35.37 & 0.594 \\
& $(1.32)$ & $(0.52)$ & $(-0.59)$ & $(1.47)$ \\
Log (Population) & $3.338^{* *}$ & 0.241 & -47.46 & $0.401^{*}$ \\
Cons & $(2.10)$ & $(1.34)$ & $(-1.09)$ & $(1.69)$ \\
Year effects & -38.27 & -1.333 & 1613.7 & $-11.31^{* *}$ \\
Country effects & $(-1.06)$ & $(-0.38)$ & $(1.64)$ & $(-2.06)$ \\
\hline $\mathrm{N}$ & Yes & Yes & Yes & Yes \\
No. countries & No & No & No & No \\
$\mathrm{R}^{2}$ & 380 & 371 & 491 & 487 \\
\hline $\mathrm{N}$ & 40 & 40 & 40 & 29 \\
\hline
\end{tabular}

Notes: Cluster robust $t$ statistics in parentheses. ${ }^{*} p<0.10,{ }^{* *} p<0.05,{ }^{* * *} p<0.01$. Models (1)-(3) are based on pooled OLS, (4) is based on a pooled probit model. Reference categories: Legal origin: Civil law (French), Colonial type: extraction, Case law: no. For model (4), Case law $=$ yes is perfectly collinear with Common British $=1$, therefore corresponding countries are dropped from the regression. 
Table 9: Institutional determinants of banking system development in African countries 2005-2015 (pooled OLS regressions)

\begin{tabular}{|c|c|c|c|c|c|}
\hline & \multicolumn{2}{|c|}{ Depth } & \multirow{2}{*}{$\begin{array}{c}\frac{\text { Breadth }}{\text { Deposits }} \\
\text { to GDP }\end{array}$} & \multicolumn{2}{|c|}{ Intermediation } \\
\hline & $\begin{array}{l}\text { Private } \\
\text { credit }\end{array}$ & $\begin{array}{l}\text { Liquid } \\
\text { liab to GDP }\end{array}$ & & $\begin{array}{l}\text { Loans } \\
\text { to deposits }\end{array}$ & NIM \\
\hline \multirow[t]{2}{*}{ Creditor rights } & -0.171 & $-0.380^{* *}$ & $-0.360^{* *}$ & $0.285^{*}$ & 0.00210 \\
\hline & $(-1.50)$ & $(-2.11)$ & $(-2.13)$ & $(1.81)$ & $(0.13)$ \\
\hline \multirow[t]{2}{*}{ Investor protection } & 2.226 & -1.378 & -0.0134 & 3.704 & 0.128 \\
\hline & $(0.94)$ & $(-0.60)$ & $(-0.01)$ & $(1.31)$ & $(0.41)$ \\
\hline \multirow[t]{2}{*}{ Enforcing contracts } & $-0.0125^{* *}$ & $-0.0199^{*}$ & $-0.0136^{*}$ & -0.0149 & 0.000246 \\
\hline & $(-2.05)$ & $(-1.87)$ & $(-2.00)$ & $(-1.11)$ & $(0.22)$ \\
\hline \multirow[t]{2}{*}{ Legal origin: common law } & $10.27^{*}$ & $17.28^{*}$ & $18.78^{* *}$ & -2.512 & $1.759^{* *}$ \\
\hline & $(1.72)$ & $(1.89)$ & $(2.18)$ & $(-0.22)$ & $(2.06)$ \\
\hline \multirow{2}{*}{ Colonial type: settler } & 6.749 & $16.99^{* * *}$ & $13.31^{* *}$ & -2.974 & 0.450 \\
\hline & $(1.30)$ & $(2.98)$ & $(2.45)$ & $(-0.42)$ & $(0.61)$ \\
\hline \multirow{2}{*}{ Case law: yes } & $-9.554^{*}$ & -9.132 & -6.291 & $-27.56^{* *}$ & 0.872 \\
\hline & $(-1.83)$ & $(-1.40)$ & $(-1.08)$ & $(-2.33)$ & (1.09) \\
\hline \multirow[t]{2}{*}{ Log (GDPpercapita) } & 3.870 & -3.186 & 1.151 & 5.446 & $-1.341^{* * *}$ \\
\hline & (1.07) & $(-0.93)$ & $(0.33)$ & $(1.24)$ & $(-3.17)$ \\
\hline \multirow[t]{2}{*}{ Log (Population) } & -0.773 & $-7.204^{* * *}$ & $-4.491^{*}$ & 4.750 & -0.0182 \\
\hline & $(-0.29)$ & $(-3.03)$ & $(-1.70)$ & $(1.48)$ & $(-0.05)$ \\
\hline \multirow[t]{2}{*}{ Cons } & -0.866 & $175.6^{* * *}$ & 86.42 & -63.46 & $13.54^{*}$ \\
\hline & $(-0.01)$ & $(2.92)$ & (1.39) & $(-0.82)$ & $(1.76)$ \\
\hline Year effects & Yes & Yes & Yes & Yes & Yes \\
\hline Country effects & No & No & No & No & No \\
\hline$N$ & 341 & 335 & 329 & 344 & 326 \\
\hline No. countries & 40 & 39 & 38 & 40 & 40 \\
\hline $\mathrm{R}^{2}$ & 0.355 & 0.342 & 0.405 & 0.265 & 0.362 \\
\hline
\end{tabular}

Notes: Cluster robust $t$ statistics in parentheses; ${ }^{*} p<0.10,{ }^{* *} p<0.05,{ }^{* * *} p<0.01$.

Ref. category Legal origin: Civil law (French), Reference categories: Legal origin:

Civil law (French), Colonial type: extraction, Case law: no. 
Table 10: Institutional determinants of banking system development (Hausman-Taylor panel model)

\begin{tabular}{|c|c|c|c|c|c|}
\hline & \multicolumn{2}{|c|}{ Depth } & \multirow{2}{*}{$\begin{array}{l}\frac{\text { Breadth }}{\text { Deposits }} \\
\text { to GDP }\end{array}$} & \multicolumn{2}{|c|}{ Intermediation } \\
\hline & $\begin{array}{l}\text { Private } \\
\text { credit }\end{array}$ & $\begin{array}{c}\text { Liquid } \\
\text { liab to GDP }\end{array}$ & & $\begin{array}{l}\text { Loans to } \\
\text { deposits }\end{array}$ & NIM \\
\hline \multirow[t]{2}{*}{ Creditor rights } & -0.000322 & 0.0352 & 0.0137 & 0.0135 & $-0.0254^{* *}$ \\
\hline & $(-0.01)$ & $(1.00)$ & $(0.45)$ & $(0.13)$ & $(-2.29)$ \\
\hline \multirow[t]{2}{*}{ Investor protection } & 0.158 & $-0.985^{*}$ & $-1.031^{* *}$ & 2.781 & 0.170 \\
\hline & $(0.38)$ & $(-1.66)$ & $(-2.44)$ & $(1.50)$ & $(0.59)$ \\
\hline \multirow{2}{*}{ Enforcing contracts } & 0.000707 & 0.00571 & 0.00609 & 0.00276 & -0.00139 \\
\hline & $(0.14)$ & $(0.65)$ & $(0.74)$ & $(0.23)$ & $(-0.64)$ \\
\hline \multirow[t]{2}{*}{ Legal origin: common law } & $7.067^{* *}$ & 7.255 & $9.807^{* *}$ & 5.238 & $2.528^{* *}$ \\
\hline & $(2.34)$ & $(0.88)$ & $(2.12)$ & $(0.59)$ & $(1.97)$ \\
\hline \multirow[t]{2}{*}{ Colonial type: settler } & $11.80^{* * *}$ & 5.345 & $10.28^{* *}$ & 7.722 & 0.716 \\
\hline & $(2.72)$ & $(0.75)$ & $(2.18)$ & $(0.79)$ & $(0.71)$ \\
\hline \multirow[t]{2}{*}{ Case law: yes } & $-4.190^{*}$ & -11.17 & -3.012 & $-16.69^{*}$ & 0.654 \\
\hline & $(-1.80)$ & $(-1.15)$ & $(-0.62)$ & $(-1.76)$ & $(0.51)$ \\
\hline \multirow[t]{2}{*}{ Log (GDPpercapita) } & $-2.550^{* *}$ & $-6.932^{* *}$ & -2.008 & -2.202 & -0.562 \\
\hline & $(-1.97)$ & $(-2.32)$ & $(-1.15)$ & $(-0.28)$ & $(-1.40)$ \\
\hline \multirow[t]{2}{*}{ Log (Population) } & -3.439 & 3.148 & -2.687 & -3.558 & -0.390 \\
\hline & $(-1.51)$ & $(0.60)$ & $(-0.86)$ & $(-0.63)$ & $(-1.04)$ \\
\hline \multirow[t]{2}{*}{ Cons } & $79.34^{* *}$ & 18.48 & 67.85 & 123.3 & $14.83^{* *}$ \\
\hline & $(2.00)$ & $(0.23)$ & (1.29) & $(1.15)$ & $(2.14)$ \\
\hline Year effects & Yes & Yes & Yes & Yes & Yes \\
\hline Country effects (RE) & Yes & Yes & Yes & Yes & Yes \\
\hline $\mathrm{N}$ & 341 & 335 & 329 & 344 & 326 \\
\hline No. countries & 40 & 39 & 38 & 40 & 40 \\
\hline$\chi^{2}$ statistic & $889.4^{* * *}$ & $194.3^{* * *}$ & $199.4^{* * *}$ & $3251.6^{* * *}$ & $733.4^{* * *}$ \\
\hline
\end{tabular}

Notes: Cluster robust $t$ statistics in parentheses; ${ }^{*} p<0.10,{ }^{* *} p<0.05,{ }^{* * *} p<0.01$. Endogenous variables: Creditor rights, Investor protection, Enforcing contracts. Instruments: $\log ($ GDPpercapita), $\log$ (Population), Legal origin, colonial type, case law. Reference categories: Legal origin: Civil law (French), Colonial type: extraction, Case law: no. 
Table 11: Institutional determinants of banking system development with differentiated legal origin (Hausman-Taylor panel model)

\begin{tabular}{|c|c|c|c|c|c|}
\hline & \multicolumn{2}{|c|}{ Depth } & \multirow{2}{*}{$\begin{array}{c}\frac{\text { Breadth }}{\text { Deposits }} \\
\text { to GDP }\end{array}$} & \multicolumn{2}{|c|}{ Intermediation } \\
\hline & $\begin{array}{l}\text { Private } \\
\text { credit }\end{array}$ & $\begin{array}{c}\text { Liquid } \\
\text { liab to GDP }\end{array}$ & & $\begin{array}{l}\text { Loans to } \\
\text { deposits }\end{array}$ & NIM \\
\hline \multirow[t]{2}{*}{ Creditor rights } & -0.00168 & 0.0350 & 0.0131 & 0.0117 & $-0.0254^{* *}$ \\
\hline & $(-0.05)$ & $(0.99)$ & $(0.43)$ & $(0.11)$ & $(-2.29)$ \\
\hline \multirow[t]{2}{*}{ Investor protection } & 0.169 & $-0.991^{*}$ & $-1.026^{* *}$ & 2.819 & 0.167 \\
\hline & $(0.40)$ & $(-1.67)$ & $(-2.40)$ & $(1.52)$ & $(0.58)$ \\
\hline \multirow[t]{2}{*}{ Enforcing contracts } & 0.000599 & 0.00558 & 0.00603 & 0.00307 & -0.00135 \\
\hline & $(0.12)$ & $(0.63)$ & $(0.73)$ & $(0.25)$ & $(-0.63)$ \\
\hline \multirow[t]{2}{*}{ Common law: British } & -0.679 & 7.268 & 5.300 & -16.09 & $4.512^{* * *}$ \\
\hline & $(-0.09)$ & $(0.47)$ & $(0.53)$ & $(-0.97)$ & $(2.89)$ \\
\hline \multirow[t]{2}{*}{ Common law: mixed } & $26.48^{* *}$ & $34.77^{*}$ & 23.26 & 15.69 & -0.0768 \\
\hline & $(2.23)$ & $(1.72)$ & $(1.64)$ & $(0.87)$ & $(-0.05)$ \\
\hline \multirow[t]{2}{*}{ Civil law: mixed } & 2.771 & 15.84 & 3.225 & -15.80 & 0.567 \\
\hline & $(0.49)$ & $(0.96)$ & $(0.34)$ & $(-1.34)$ & $(0.44)$ \\
\hline \multirow[t]{2}{*}{ Colonial type: settler } & $7.860^{* *}$ & 1.045 & 7.317 & 3.287 & 1.309 \\
\hline & $(2.32)$ & $(0.13)$ & $(1.61)$ & $(0.39)$ & $(1.46)$ \\
\hline \multirow[t]{2}{*}{ Case law: yes } & -1.688 & -13.06 & -1.914 & -6.551 & -0.219 \\
\hline & $(-0.28)$ & $(-0.86)$ & $(-0.22)$ & $(-0.50)$ & $(-0.15)$ \\
\hline \multirow[t]{2}{*}{ Log (GDPpercapita) } & $-3.135^{* * *}$ & $-7.083^{* *}$ & -2.250 & -2.872 & -0.473 \\
\hline & $(-2.72)$ & $(-2.32)$ & $(-1.27)$ & $(-0.36)$ & $(-1.17)$ \\
\hline \multirow[t]{2}{*}{ Log (Population) } & -1.779 & 3.555 & -2.057 & -2.080 & -0.527 \\
\hline & $(-0.73)$ & $(0.69)$ & $(-0.65)$ & $(-0.33)$ & $(-1.51)$ \\
\hline \multirow[t]{2}{*}{ Cons } & 56.78 & 8.851 & 59.07 & 109.4 & $16.18^{* *}$ \\
\hline & $(1.43)$ & $(0.11)$ & $(1.14)$ & $(0.99)$ & $(2.50)$ \\
\hline Year effects & Yes & Yes & Yes & Yes & Yes \\
\hline Country effects (RE) & Yes & Yes & Yes & Yes & Yes \\
\hline $\mathrm{N}$ & 341 & 335 & 329 & 344 & 326 \\
\hline No. countries & 40 & 39 & 38 & 40 & 40 \\
\hline$\chi^{2}$ statistic & $1047.8^{* * *}$ & $277.6^{* * *}$ & $297.4^{* * *}$ & $4091.7^{* * *}$ & $776.9^{* * *}$ \\
\hline
\end{tabular}


Table 12: Institutional determinants of banking system development with institutional quality controls (Hausman-Taylor panel model)

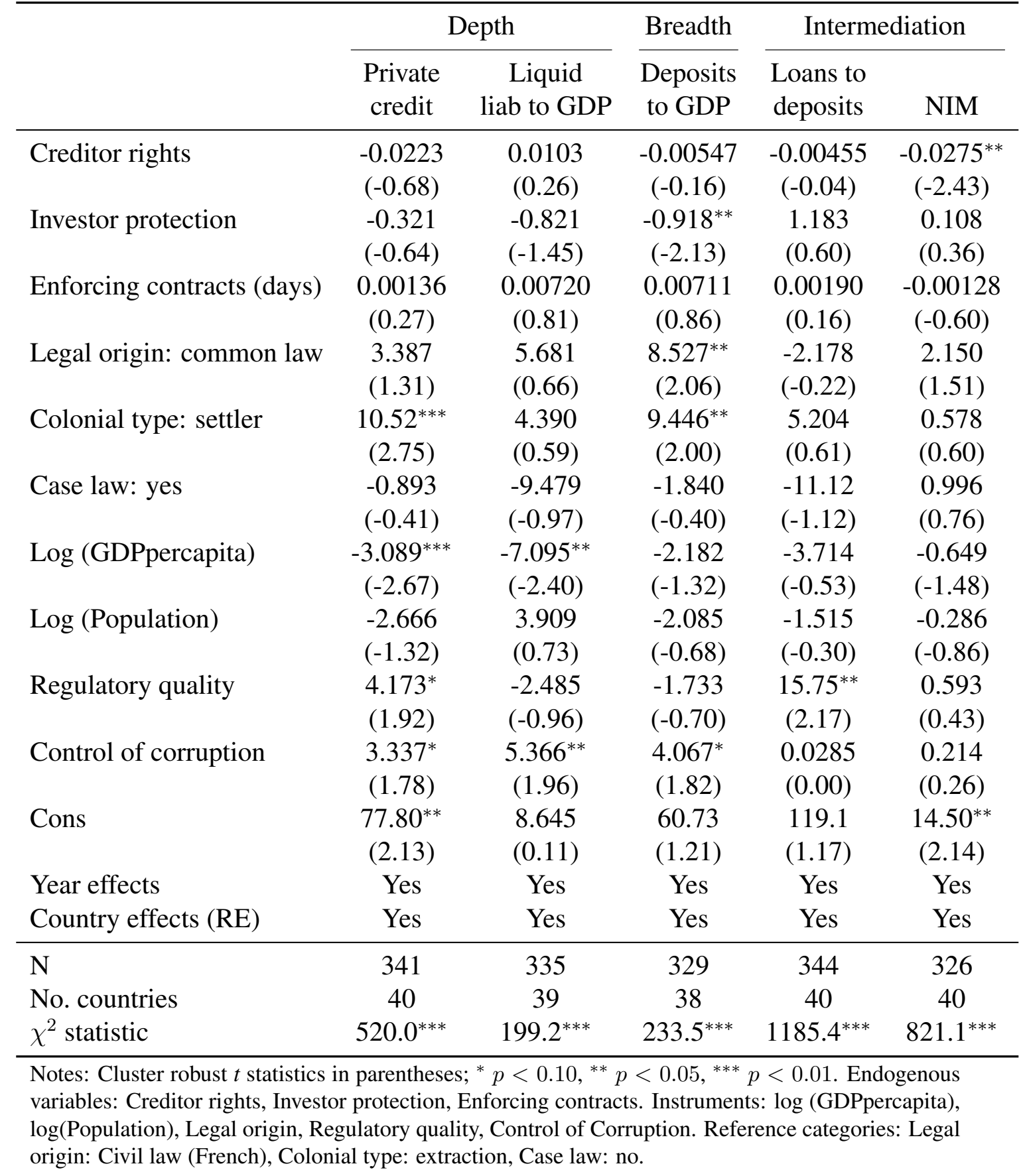


Table 13: Institutional determinants of banking system development (fixed effects panel regressions)

\begin{tabular}{|c|c|c|c|c|c|}
\hline & \multicolumn{2}{|c|}{ Depth } & \multirow{2}{*}{$\begin{array}{c}\frac{\text { Breadth }}{\text { Deposits }} \\
\text { to GDP }\end{array}$} & \multicolumn{2}{|c|}{ Intermediation } \\
\hline & $\begin{array}{l}\text { Private } \\
\text { credit }\end{array}$ & $\begin{array}{c}\text { Liquid } \\
\text { liab to GDP }\end{array}$ & & $\begin{array}{l}\text { Loans to } \\
\text { deposits }\end{array}$ & NIM \\
\hline \multirow[t]{2}{*}{ Creditor rights } & -0.000655 & 0.0233 & 0.00664 & 0.0402 & $-0.0215^{* *}$ \\
\hline & $(-0.02)$ & $(0.64)$ & $(0.21)$ & $(0.41)$ & $(-2.03)$ \\
\hline \multirow[t]{2}{*}{ Investor protection } & 0.206 & -0.908 & $-0.965^{* *}$ & 2.723 & 0.136 \\
\hline & $(0.47)$ & $(-1.36)$ & $(-2.03)$ & $(1.39)$ & $(0.53)$ \\
\hline \multirow[t]{2}{*}{ Enforcing contracts } & 0.00155 & 0.00554 & 0.00620 & 0.00365 & -0.00129 \\
\hline & $(0.30)$ & $(0.64)$ & $(0.75)$ & $(0.31)$ & $(-0.62)$ \\
\hline \multirow[t]{2}{*}{ Log (GDPpercapita) } & -3.507 & $-10.91^{* * *}$ & $-4.650^{*}$ & 3.691 & 0.890 \\
\hline & $(-1.28)$ & $(-2.78)$ & $(-1.82)$ & $(0.31)$ & $(1.06)$ \\
\hline \multirow[t]{2}{*}{ Log (Population) } & -3.154 & $18.02^{*}$ & 6.416 & -32.92 & $-5.479^{* *}$ \\
\hline & $(-0.39)$ & $(1.91)$ & $(0.90)$ & $(-1.13)$ & $(-2.18)$ \\
\hline \multirow[t]{2}{*}{ Cons } & 85.03 & -189.7 & -52.44 & 542.4 & $87.27^{* *}$ \\
\hline & $(0.74)$ & $(-1.49)$ & $(-0.53)$ & $(1.39)$ & $(2.45)$ \\
\hline Year effects & Yes & Yes & Yes & Yes & Yes \\
\hline Country effects (FE) & Yes & Yes & Yes & Yes & Yes \\
\hline $\mathrm{N}$ & 341 & 335 & 329 & 344 & 326 \\
\hline No. countries & 40 & 39 & 38 & 40 & 40 \\
\hline $\mathrm{R}^{2}$ & 0.469 & 0.491 & 0.550 & 0.143 & 0.206 \\
\hline
\end{tabular}

Notes: Cluster robust $t$ statistics in parentheses; ${ }^{*} p<0.10,{ }^{* *} p<0.05,{ }^{* * *} p<0.01$. 
Table 14: Institutional determinants of banking system development with institutional and regulatory quality controls (fixed effects panel regressions)

\begin{tabular}{|c|c|c|c|c|c|}
\hline & \multicolumn{2}{|c|}{ Depth } & \multirow{2}{*}{$\begin{array}{l}\frac{\text { Breadth }}{\text { Deposits }} \\
\text { to GDP }\end{array}$} & \multicolumn{2}{|c|}{ Intermediation } \\
\hline & $\begin{array}{l}\text { Private } \\
\text { credit }\end{array}$ & $\begin{array}{c}\text { Liquid } \\
\text { liab to GDP }\end{array}$ & & $\begin{array}{l}\text { Loans to } \\
\text { deposits }\end{array}$ & NIM \\
\hline \multirow[t]{2}{*}{ Creditor rights } & -0.0220 & -0.00109 & -0.0114 & 0.0167 & $-0.0244^{* *}$ \\
\hline & $(-0.68)$ & $(-0.03)$ & $(-0.33)$ & $(0.16)$ & $(-2.18)$ \\
\hline \multirow[t]{2}{*}{ Investor protection } & -0.246 & -0.821 & $-0.855^{*}$ & 1.320 & 0.0916 \\
\hline & $(-0.49)$ & $(-1.36)$ & $(-1.89)$ & $(0.62)$ & $(0.33)$ \\
\hline \multirow[t]{2}{*}{ Enforcing contracts (days) } & 0.00219 & 0.00696 & 0.00728 & 0.00340 & -0.00121 \\
\hline & $(0.42)$ & $(0.80)$ & $(0.88)$ & $(0.29)$ & $(-0.59)$ \\
\hline \multirow[t]{2}{*}{ Log (GDPpercapita) } & $-4.499^{*}$ & $-11.12^{* * *}$ & $-4.857^{*}$ & 1.243 & 0.762 \\
\hline & $(-1.80)$ & $(-2.79)$ & $(-1.91)$ & $(0.11)$ & $(0.79)$ \\
\hline \multirow[t]{2}{*}{ Log (Population) } & -0.758 & $18.76^{*}$ & 7.063 & -27.42 & $-5.185^{*}$ \\
\hline & $(-0.10)$ & $(1.93)$ & $(0.96)$ & $(-0.96)$ & $(-1.97)$ \\
\hline \multirow[t]{2}{*}{ Regulatory quality } & $4.034^{*}$ & -1.669 & -1.648 & $13.87^{*}$ & 0.420 \\
\hline & $(1.75)$ & $(-0.62)$ & $(-0.66)$ & $(1.76)$ & $(0.28)$ \\
\hline \multirow[t]{2}{*}{ Control of corruption } & 2.924 & $5.064^{*}$ & $3.846^{*}$ & 0.645 & 0.356 \\
\hline & $(1.57)$ & $(1.93)$ & $(1.75)$ & $(0.08)$ & $(0.44)$ \\
\hline \multirow[t]{2}{*}{ Cons } & 59.98 & -198.6 & -60.43 & 486.9 & $84.09^{* *}$ \\
\hline & $(0.58)$ & $(-1.54)$ & $(-0.60)$ & $(1.27)$ & $(2.32)$ \\
\hline \multicolumn{6}{|l|}{$(2.45)$} \\
\hline Year effects & Yes & Yes & Yes & Yes & Yes \\
\hline Country effects (FE) & Yes & Yes & Yes & Yes & Yes \\
\hline $\mathrm{N}$ & 341 & 335 & 329 & 344 & 326 \\
\hline No. countries & 40 & 39 & 38 & 40 & 40 \\
\hline $\mathrm{R}^{2}$ & 0.497 & 0.504 & 0.559 & 0.161 & 0.208 \\
\hline
\end{tabular}

Notes: Cluster robust $t$ statistics in parentheses; ${ }^{*} p<0.10,{ }^{* *} p<0.05,{ }^{* * *} p<0.01$. 